\title{
People's Preferences and Attitudes about Spiritual Leadership Values in Public Organization: The Case of Turkey
}

\author{
Dr. Vural Karagul \\ District Governor of Esenyurt \\ Republic of Turkey Ministry of Interior, Istanbul, Turkey
}

Received: Feb. 19, 2017 Accepted: Sep. 8, $2019 \quad$ Published: October 1, 2019

doi:10.5296/jmr.v11i4.15118～URL: https://doi.org/10.5296/jmr.v11i4.15118

\begin{abstract}
The purpose of this study is to examine if Turkish people prefer their leaders with spiritual leadership characteristics. The findings reveal that Turkish people prefer their leaders with spiritual values and characteristics. In addition, Turkish people in both the East and West part of Turkey, after spiritual leadership values and characteristics, want to see their leaders with religious values. However, the magnitude of preferences of religious values in the East part of Turkey is higher than in the West part of Turkey.

These results can be implemented training the high ranked government officials such as bureaucrats and district governors to empower them with spiritual leadership values and characteristics; therefore, they could provide better services for the benefits of people. Also, political parties can bring spiritual leadership values to their agenda. They can emphasize on these values in their party programs and to raise awareness among the party leaders and members to inspire and sustain people.
\end{abstract}

Keywords: Leadership, Public organization, Spiritually, Values 


\section{Introduction}

Spirituality plays an important role in both business organizations and public organizations. According to Skolimowski (1999), there is a very close relationship between the state of human wisdom and the state of human soul, and if people's spirits do not work, organizations do not function properly. Spiritual blight affects people's individual lives and their organizations alike. If people's visions are narrow and their wisdom limited, their political organizations suffer (Skolimowski, 1999).

Taking together with literature review and in-depth analysis of political patterns throughout Muslim countries, the contemporary leadership concept exposed several weaknesses (AlSarhi et al., 2014). According to Abbasi et al. (2010), the reason for these weaknesses is the lack of two main factors - namely, values and accountability. In Muslim countries, people expect leaders to display such characteristics and attitudes as fairness, but these must be rooted in the Quran, Sunnah, and Islam's hierarchy of references (AlSarhi et al., 2014). However, these types of expectations have received scarce attention, because leaders tend to adopt strategies and actions from the West (AlSarhi et al., 2014). This doubt against leaders may have led people to prioritize spiritual leadership and values in their leaders. The fact that religious and spiritual issues have been voiced as the spiritual development slogan highlights the deep impact of enlightenment rationalist philosophy and its teleological ideas of progress and development (Yildiz, 2003). This is facilitated by the increasing secularization of the Turks, which has made support for a radical religious revival less likely, and the increasing moderation of the worldviews of religious groups themselves. Therefore, it is worth examining whether Turkish people expect their leaders to embody spiritual values, which are honesty, trustworthiness, fairness, integrity, humility, ethics, faith, and religion. This study contributes to existing literature on the importance of spiritual leadership values and characteristics in public organizations.

These results can be implemented in training high-ranked government officials such as bureaucrats and district governors to empower them with spiritual leadership values and characteristics so that they can better serve the Turkish people. They can also be used to help political parties bring spiritual leadership values to their agenda, emphasizing these values in their party programs and raising awareness among party leaders and members to inspire and sustain the Turkish people.

The rest of the study is organized as follows: Section 2 gives the literature review, Section 3 presents the methodology and data, Section 4 evaluates the findings, and Section 5 concludes the study.

\section{Literature Review}

Turkish society is strongly based on family values, which are reified in many areas of social life. For example, the daily press and the speeches of public figures make frequent reference to the Turkish family structure as a way to judge the public and private actions of individuals. Therefore, human resource practices, such as managerial communication and participative management, would have a strong effect on trust in leader in Turkish organizations (Erturk, 
2006).

Public spiritual well-being could be related to the behaviors of leaders toward and the degree of comfort leaders enjoy in providing spiritual care. Since leaders are committed to the care of the public, they may have to incorporate spiritual care into their practice. There is a positive correlation between the spiritual well-being and attitude of a leader and his or her level of comfort in providing spiritual care for co-workers. Leaders have to think and deal with making themselves and then assisting followers make this connection (Fairholm, 1997). This kind of leader will look for and find people who place more value on the spiritual side of life than on materialistic values (Fairholm, 1997).

People expect leaders to have some qualities such as wisdom, goodness, and honesty. Without wisdom, leaders might make wrong decisions. Without goodness, they might make immoral rules. Moreover, without honesty, they might show favoritism. However, with all three characteristics, they would be good leaders (Fairholm, 1997).

Spiritual leadership is related with the essential needs of both leaders and followers for intangible survival so they become more organizationally committed and productive (Mansor et al, 2013; Fry, 2003).

Spiritual leadership is consisted of four primary dimensions, namely; religiousness, interconnectedness, sense of mission, and wholeness (Mansor et al, 2013; Sendjaya, 2007). Giacalone and Jurkiewicz (2003) offer another definition of spiritual leadership that is a framework of organizational values evidenced in the culture that promotes employees' experience of transcendence through the work process, facilitating their sense of being connected in a way that provides feelings of compassion and joy.

Deep integration of leaders' spirituality and work lives leads to affirmative changes in their relationships and effectiveness (Fry, 2003; Neal, 2001). Giacalone and Jurkiewicz (2003) prove that workplace spirituality programs, in addition to leading to beneficial personal outcomes such as increased joy, peace, serenity, job satisfaction, and commitment, also deliver improved productivity and reduce absenteeism and turnover. Employees consider leaders who are spiritual to be less fearful, more ethical, and more committed. In addition, there is evidence that a more spiritual workplace is more productive, flexible, and creative (Fry, 2003; Eisler and Montouori, 2003).

Both religion and spirituality require faith as a foundation. Faith is the guiding principle by which individuals are either religious or spiritual. It serves as both the source and the target of their religion or spirituality (Newman, 2004).

To avoid any potential disruptive clashes arising from a vast range of religious beliefs or rituals, spirituality is often identified in opposition to religion in leadership studies (Sendjaya, 2007; Hicks, 2002; Korac-Kakabadse, Kouzmin, and Kakabadse, 2002). According to Hicks (2002), religion is often regarded as institutional, dogmatic, and rigid, whereas spirituality is personal, emotional, and adaptable to an individual's needs; as he concludes, "spirituality unites, but religion divides" (Sendjaya, 2007; Hicks, 2002). 


\section{Mll Macrothink}

Journal of Management Research

ISSN 1941-899X

2019, Vol. 11, No. 4

Because of their susceptibility to ideological conflicts, religious beliefs and practices are excluded from descriptions of spirituality in leadership studies (Hicks, 2002). However, spirituality cannot be separated from religiousness completely (Fairholm, 1997), because spirituality is historically rooted in religion (Sendjaya, 2007; Cavanagh, 1999). Although Fry (2003) insists that spiritual leadership might or might not embrace religious theory and practice, he found that most literature on spiritual leadership derives from religious theology (Sendjaya, 2007; Fry, 2003; Banks \& Powell, 2000; Blackaby and Blackaby, 2001). Some rituals of spirituality, such as prayer, yoga, and meditation, are the sources for some people's search for spiritual survival and sense of interrelationship with other beings (Fry, 2003; Zinnbauer, Pargament and Scott, 1999). By the means of these ritual practices, leaders develop positive relationships with others, with the self, and with God (Reave, 2005).

Such spiritual values as integrity, honesty, and humility have usually been found to be main components of leadership achievement. For instance, personal integrity has been shown to be the most crucial component for generating follower respect and trust (Reave, 2005). Spiritual leadership is the practice of behaving toward others with love and compassion: showing respect, demonstrating fairness, expressing care, listening attentively, and appreciating others' gifts and contributions (Reave, 2005).

In fact, spirituality goes beyond dedication, mission, or vision and provides the support necessity to make each of this work in our individual and professional lives. Spirituality means a relationship with something intangible beyond the self and is a main source of personal values and meaning. It is also a way of perceiving self and the world, and a mean of personal and group integration. Private and public sector managers in one survey suggest that spiritual leaders embody ultimate ethical values such as integrity, independence, and justice (Fairholm, 1996).

\subsection{Spiritual values and leadership success}

\subsubsection{Integrity}

Personal integrity is the starting point for leadership success, which is reflected in ethical behavior (Hendricks \& Hendricks, 2003).

Although researches find that followers tend to look first at who a leader is, behavioral theories usually focus instead on the issue of what a leader does (Burton and O'Reilly, 2000; O’Reilly and Pfeffer, 2000).

\subsubsection{Trust}

Trust is usually related with conditions involving personal conflict, outcome uncertainty, problem solving and characterized as a positive force simplifying cooperation. Fairness, confidence, and risk-taking are perceived as three primary components of trust (Erturk, 2006; Nyhan, 2000).

According to a study examining the combined effects of the perception of fairness and trust in supervisors on the organizational citizenship behavior of scholars at public universities in Turkey, Erturk (2006) found that all dimensions of perception of fairness are significantly and 
positively related to trust in supervisors.

According to Bennis and O'Toole (2000), integrity, provide meaning, generate trust, and communicate values real leaders are great (Reave, 2005; Bennis \& O’Toole, 2000). Becker (2000) studied employees' perceptions of integrity in organizations and found that one of the hallmarks of high integrity is trustworthiness.

Trust has been shown to be important to measurable organizational outcomes as well. A significant positive correlation is found between trust and worker job satisfaction, job performance, organizational commitment, and retention (Dirks and Ferrin, 2002).

\subsubsection{Ethical well-being}

Ethical well-being is understood as necessary but not sufficient for spiritual well-being. Spiritual well-being also combines superiority of self in pursuit of a vision/purpose/mission in service to main stakeholders to meet one's need for spiritual survival through calling and membership (Fry et al., 2007).

Leader integrity has an effect on the ethical climate in an organization, influencing the ethical choices of workers. For instance, one study found that the ethical behavior of supervisors either positively or negatively influenced the ethical climate for workers (Reave, 2005; Lewicki, Dineen and Tomlinson, 2001). Correlatively, another study found that leaders generate a climate that affects the ethical decisions of followers. An examination of 446 salespeople's responses to 14 ethics-related scenarios showed that in an atmosphere of laissez faire leadership in which output was emphasized, salespeople advocated less ethical behavior (Robertson and Anderson, 1993).

\subsubsection{Honest communication}

The most acclaimed characteristic of leaders is honesty (Russell, 2001; Kouzes and Posner, 1993; Posner and Schmidt, 1992). According to Clawson (1999), honesty and integrity form the moral foundation of effective leadership through the four key values of truth telling, promise keeping, fairness, and respect for the individual (Clawson, 1999; Russell, 2001).

Leaders are usually regarded as the ones who have to account for why change is necessary and the direction it should take. Recent research has indicated that information sharing and communication lower ambiguity about change (Erturk, 2006)

According to the GLOBE study of leadership prototypes, which has grown to 17,000 managers in 900 companies in 62 countries, honesty is one of the few positive leadership features that have been universally accepted (Dorfman, Hanges, and Brodbeck, 2004).

A survey of 77 managers showed two commonalities among leaders who had maintained successful communication during layoffs and other difficult times: honest and proactive communication of the truth and explanation of the reasons for change, and listening responsively to employee needs (Bates, 2002).

\subsubsection{Humility}

Leaders should have humility for the success and effectiveness on community. Humility has 
been found to be related to leadership effectiveness in empirical studies. For instance, one way to test humility is to compare self-ratings with ratings by others, which in one study showed that leaders who rated themselves lowest were rated highest by their followers (Fleenor, McCauley, and Brutus, 1996). On the other hand, managers who overrated themselves were considered by employees to be less effective (Van Velsor et al., 1993).

To my knowledge, there is no study investigating whether people in Turkey expect spiritual values from local, high-ranked government officials and provincial government leaders, who are always elected or appointed. In addition, there is no research on whether there is a difference between the eastern and western Turkey in terms of people's expectations about spiritual values in their leaders. Therefore, this study contributes to the field in terms of measuring people's expectations for both elected and appointed leaders regarding spiritual values and characteristics. Also, it is unique in identifying the differences between the eastern and western parts of the country. Therefore, this study investigates the following research questions:

1. Is there any difference between the eastern and western parts of Turkey in terms of expectations toward spiritual leadership values?

2. Is there any difference between the eastern and western parts of Turkey in terms of expectations that public officials will possess religious leadership values?

3. Do Turkish people prefer spiritual leaders or non-spiritual leaders?

4. Do Turkish people prefer spiritual leaders over religious leaders?

\section{Research methodology and Research Design}

This study aims to explore whether Turkish people prefer leaders with spiritual values and characteristics. As such, it examines the characteristics of spiritual leaders, spiritual leader values, and perceptions and viewpoints of people towards spiritual leadership in Turkey. In order to examine people's governance and leadership preferences, a survey questionnaire with both quantitative and qualitative components was developed and administered to around three hundred people living in eastern and western Turkey.

In the survey questionnaire, the word "spirituality" was not used, since Turkish participants might misunderstand or misinterpret the meaning of the term because of the language differences between English and Turkish. Instead, values that have long been considered spiritual ideals, such as integrity, honesty, and humility, and characteristics in the spiritual values and practices as related to leadership effectiveness, which is categorized as the dimensions of spiritual values, were used as proxies for spirituality (Reave, 2005). Den Hartog at al. (1999) emphasize that more than half of the universally endorsed leader attributes are associated with spirituality; these include being ethical, positive, trustworthy, just, communicative, excellence-oriented, honest, dynamic, motivational, and dependable, as well as being a win-win problem solver, confidence builder, and team builder. Therefore, honesty, integrity, fairness, trustworthiness, humility, faith, respect, and ethics are the constructs used in the survey to assess if people want to see spiritual values from leaders. 


\subsection{Participant}

In this study, participants who were born and raised in Turkey were chosen from both eastern and western regions of Turkey. The total sample size of this study is 260 while effect size: 0.25 , alpha err prob: 0.05 , power: 0.8 , number of groups: 10 .

Three provinces were selected from both eastern and western Turkey. For western Turkey, these provinces were Bilecik, Ankara, and Istanbul. Ankara and Istanbul have the largest and the most diverse populations in western Turkey. The reason these cities were chosen was to ensure the objectivity and diversity in the study. The three provinces from eastern Turkey were Sanliurfa, Batman, and Sirnak, which are cities home to the most fundamentalist Kurdish nationalism.

In order to ensure equity, the survey was conducted in communal areas such as state buildings. In Turkey, such state buildings have important an important public presence and many diverse people visit them for different purposes. The various state buildings used to administer the survey included registration offices, national education offices, national tax offices, social aid offices, and others.

\section{Inclusion Criteria}

Below are some inclusion criteria, which participants are supposed to have:

1. Participants who are born and raised in the region.

2. Participants who are literate.

3. Participants who are over 18.

\section{Exclusion Criteria}

Below are some exclusion criteria, which participants are supposed to have:

1. Foreign people who have been living in the region as a permanent resident.

2. People who are illiterate.

3. People who are members of a political organization.

Measures

Demographics: A demographic questionnaire is used in order to provide principal information. This questionnaire covers age, ethnicity, citizenship, occupation, income, and religion.

\subsection{Measurement of People's Attitudes about Spiritual Leadership}

The theoretical literature on attitudes is broad, and approaches to measuring attitudes range from simple approaches that use straightforward ranking and rating questions, to more complex approaches that distinguish attitudes, perceptions, values, and beliefs (Phillips et al, 2002).

In this study, attitude survey, which is the most commonly, used approach in surveys for 
measuring attitudes with ranking and rating questions will be adapted. Respondents were asked to rate the importance of 23 leadership values such as education, secularity, spirituality, religion, normative leaders, and good politicians on a five-point scale. For example, 9 dimensions of spirituality will be defined and asked to participants in a Likert-scale ranging from " 1 " for "strongly disagree" to "5" for "strongly agree". These 9 dimensions of spirituality will be defined as integrity, trust, fairness, respect, ethical wellbeing, honesty, humility, and faith. Participants will be asked to rate these 23 leadership values including dimensions of spirituality and religiosity from " 1 " to " 5 " in accordance with their expectations from leaders.

In order to capture people's preferences, there will also be quantitative questions. These questions will be about the expectations of people from leaders in regards to having spiritual characteristics. Participants will be asked to write the most important 7 leadership values they want to see in a leader based on definitions provided in the first question. So, participants will put these characteristics in order from the most important to least important,1st to 7th respectively. In this part of the survey, the answers of participants will be categorized into 9 divisions such as "1" for "spirituality", "2" for "religiosity", " 3 " for "normative values", "4" for "fixing economy", "5" for "secularity", "6" for "charisma", "7" for "good politician", "8" for "eliminating conflict", and "9" for "education". People's preferences will be put in order of accordance with their expectations.

In addition, participants will be allowed to write their own expectations by providing their own definitions. Since it is difficult to cover people's different opinions and expectations in the survey, allowing participants to write their own expectations will add value to the study and ensure its accuracy. Therefore, this will also provide the qualitative side of the survey.

\section{Data Analysis and Findings}

One-way ANOVA is conducted for Likert scale questions. Participants will be separated in to groups: those from the eastern provinces and those from the western provinces of Turkey. By doing this, expectations of these two groups are compared, to see if these two sets of data are significantly different from each other.

In addition, a Chi-square test is conducted to determine whether there is a significant difference between the expected frequencies and the observed frequencies in one or more categories.

\subsection{Findings}

A total of 288 participants (196 male and 92 female), 172 who reside in the western region and 116 who reside in the eastern region of Turkey with the age range from 18-24 (50 participants), 25-34 (113 participants), 35-44 (70 participants), 45-54 (36 participants), 55-64 (14 participants), 65-74 (4 participants). The participants are ethnically diverse with 170 Turks, 106 Kurds, 5 Arab, and 7. 279 Muslim, and 8 Alawite.

Education background of the participants ranges from elementary school to $\mathrm{PhD}$ with 89 bachelors' degree, 67 high school, 34 elementary, 31 college, 25 middle school, 22 high school but not graduated, 9 master, $6 \mathrm{PhD}$, and 5 with no degree. When asked, 244 
participants answered that they felt themselves religious and 42 did not. 119 of those self-identified religious participant always perform the rituals. In addition, 70 participants are members of a religious congregation, while 214 participants are not.

The scale had an acceptable level of internal consistency, as determined by a Cronbach's alpha of 0.712 for 8 items in Table 1 .

Table 1. Reliability Statistics Table of the Survey

\begin{tabular}{|r|r|r|}
\hline Cronbach's Alpha & $\begin{array}{c}\text { Cronbach's Alpha } \\
\text { Based on Standardized }\end{array}$ & \\
\hline .712 & Items & N of Items \\
\hline
\end{tabular}

Initially, the factorability of the 8 spirituality items is examined. Several well-recognized criteria for the factorability of a correlation are used. Firstly, 7 of the 8 items correlated at least 0.3 with at least one other item, suggesting reasonable factorability in Table 2 . Secondly, the Kaiser-Meyer-Olkin measure of sampling adequacy is 0.808 , above the recommended value of 0.6, and Bartlett's test of sphericity is significant ( $2(28)=510.39, \mathrm{p}<0.05)$ in Table 2.

Table 2. KMO and Bartlett's Test Table of Dimensions of Spirituality

\begin{tabular}{|c|c|c|}
\hline \multicolumn{2}{|c|}{ Kaiser-Meyer-Olkin Measure of Sampling Adequacy } & .810 \\
\hline \multirow[t]{3}{*}{ Bartlett's Test of Sphericity } & Approx. Chi-Square & 510.394 \\
\hline & df & 28 \\
\hline & Sig. & $.000 *$ \\
\hline
\end{tabular}

The diagonals of the anti-image correlation matrix are all over 0.5 (See Table 3), supporting the inclusion of each item in the factor analysis. 
Table 3. Anti-image Matrices Table of Dimensions of Spirituality

\begin{tabular}{|ll|r|r|r|r|r|r|r|r|}
\hline & & Humility & Respect & Ethical & Faith & Integrity & Fairness & Honesty & Trustworthy \\
\hline Anti-image & Humility & .747 & -.153 & -.222 & -.041 & .043 & .030 & .054 & -.130 \\
& Respect & -.153 & .734 & -.083 & .011 & -.073 & -.021 & -.104 & -.065 \\
& Ethical & -.222 & -.083 & .649 & -.030 & -.015 & -.161 & -.121 & .070 \\
& Faith & -.041 & .011 & -.030 & .952 & -.092 & -.051 & -.039 & .060 \\
& Integrity & .043 & -.073 & -.015 & -.092 & .691 & -.122 & -.026 & -.162 \\
& Fairness & .030 & -.021 & -.161 & -.051 & -.122 & .527 & -.117 & -.170 \\
& Honesty & .054 & -.104 & -.121 & -.039 & -.026 & -.117 & .629 & -.142 \\
& Trustworthy & -.130 & -.065 & .070 & .060 & -.162 & -.170 & -.142 & .544 \\
\hline Anti-image & Humility & $.721^{\mathrm{a}}$ & -.207 & -.319 & -.048 & .060 & .049 & .078 & -.204 \\
& Respect & -.207 & $.878^{\mathrm{a}}$ & -.120 & .013 & -.102 & -.033 & -.153 & -.102 \\
& Ethical & -.319 & -.120 & $.772^{\mathrm{a}}$ & -.038 & -.022 & -.275 & -.189 & .118 \\
& Faith & -.048 & .013 & -.038 & $.767^{\mathrm{a}}$ & -.113 & -.071 & -.051 & .083 \\
& Integrity & .060 & -.102 & -.022 & -.113 & $.847^{\mathrm{a}}$ & -.203 & -.040 & -.264 \\
& Fairness & .049 & -.033 & -.275 & -.071 & -.203 & $.817^{\mathrm{a}}$ & -.203 & -.318 \\
& Honesty & .078 & -.153 & -.189 & -.051 & -.040 & -.203 & $.852^{\mathrm{a}}$ & -.242 \\
& Trustworthy & -.204 & -.102 & .118 & .083 & -.264 & -.318 & -.242 & $.784^{\mathrm{a}}$ \\
\hline
\end{tabular}

a. Measures of Sampling Adequacy(MSA)

Finally, with only 1 item below, the communalities are all above 0.3 , further confirming that each item shared some common variance with other items and given these overall indicators, factor analysis is conducted with all 8 items (see Table 4).

Table 4. Communalities Table of Dimensions of Spirituality

\begin{tabular}{|l|r|r|}
\hline & Initial & \multicolumn{2}{|c|}{ Extraction } \\
\hline Humility & 1.000 & .722 \\
Respect & 1.000 & .484 \\
Ethical & 1.000 & .579 \\
Faith & 1.000 & .103 \\
Integrity & 1.000 & .601 \\
Fairness & 1.000 & .658 \\
Honesty & 1.000 & .541 \\
Trustworthy & 1.000 & .605 \\
\hline
\end{tabular}

Extraction Method: Principal Component Analysis.

1-Findings of First Section of Questionnaire: This section reports the results of the analysis of the survey research conducted in Turkey on the preferences and attitudes of people in Eastern and Western Turkey about spiritual leadership. First, participants are asked to rate and rank 
23 statements about leadership values based on their preferences. They rated these 23 statements using a 5-point Likert-scale that ranged from "strongly agree" to "strongly disagree". "A one-way ANOVA" and "a chi square test" are conducted to analyze the results. Findings are below:

1-a. Spiritual Leadership Values: A one-way ANOVA is conducted to compare the two groups in terms of their support and preferences for spiritual leadership. The results show that there is a significant difference between the Eastern region and the Western region of Turkey in terms of public's expectations of the leaders having faith at the 0.05 level for the two conditions; $\mathrm{F}(1,286)=15.446, \mathrm{p}=0.000 *(\mathrm{M}=4.61, \mathrm{SD}=0.63)$. However, with the other dimensions of spirituality such as humility, respect for people, ethics, integrity, fairness, honesty, and trustworthy, there is no statistically significant difference between the Eastern and the Western part of Turkey (See Table 5).

Table 5. ANOVA Analysis Table of Participants' Preferences about Spiritual Leadership Values

\begin{tabular}{|c|c|c|c|c|c|c|}
\hline & & Sum of Squares & df & Mean Square & $\mathrm{F}$ & Sig. \\
\hline Leaders Have & Between Groups & .529 & 1 & .529 & 1.736 & .189 \\
\hline \multirow[t]{2}{*}{ Humility } & Within Groups & 86.885 & 285 & .305 & & \\
\hline & Total & 87.415 & 286 & & & \\
\hline \multirow[t]{3}{*}{ Respect For People } & Between Groups & .033 & 1 & .033 & .319 & .572 \\
\hline & Within Groups & 29.630 & 286 & .104 & & \\
\hline & Total & 29.663 & 287 & & & \\
\hline \multirow[t]{3}{*}{ Ethical Leaders } & Between Groups & .314 & 1 & .314 & 2.058 & .153 \\
\hline & Within Groups & 43.686 & 286 & .153 & & \\
\hline & Total & 44.000 & 287 & & & \\
\hline \multirow[t]{3}{*}{ Leaders Have Faith } & Between Groups & 12.526 & 1 & 12.526 & 15.446 & $.000 *$ \\
\hline & Within Groups & 231.942 & 286 & .811 & & \\
\hline & Total & 244.469 & 287 & & & \\
\hline \multirow[t]{3}{*}{ Leaders Have Integrity } & Between Groups & .022 & 1 & .022 & .057 & .811 \\
\hline & Within Groups & 107.756 & 286 & .377 & & \\
\hline & Total & 107.778 & 287 & & & \\
\hline \multirow[t]{3}{*}{ Fair Leaders } & Between Groups & .065 & 1 & .065 & .764 & .383 \\
\hline & Within Groups & 24.404 & 286 & .085 & & \\
\hline & Total & 24.469 & 287 & & & \\
\hline \multirow[t]{3}{*}{ Honest Leaders } & Between Groups & .012 & 1 & .012 & .144 & .705 \\
\hline & Within Groups & 24.817 & 286 & .087 & & \\
\hline & Total & 24.830 & 287 & & & \\
\hline \multirow[t]{2}{*}{ Trustworthy Leaders } & Between Groups & .011 & 1 & .011 & .117 & .732 \\
\hline & Within Groups & 26.853 & 285 & .094 & & \\
\hline
\end{tabular}




\begin{tabular}{|c|c|c|c|c|c|c|}
\hline & & Sum of Squares & df & Mean Square & $\mathrm{F}$ & Sig. \\
\hline Leaders Have & Between Groups & .529 & 1 & .529 & 1.736 & .189 \\
\hline \multirow[t]{2}{*}{ Humility } & Within Groups & 86.885 & 285 & .305 & & \\
\hline & Total & 87.415 & 286 & & & \\
\hline \multirow[t]{3}{*}{ Respect For People } & Between Groups & .033 & 1 & .033 & .319 & .572 \\
\hline & Within Groups & 29.630 & 286 & .104 & & \\
\hline & Total & 29.663 & 287 & & & \\
\hline \multirow[t]{3}{*}{ Ethical Leaders } & Between Groups & .314 & 1 & .314 & 2.058 & .153 \\
\hline & Within Groups & 43.686 & 286 & .153 & & \\
\hline & Total & 44.000 & 287 & & & \\
\hline \multirow[t]{3}{*}{ Leaders Have Faith } & Between Groups & 12.526 & 1 & 12.526 & 15.446 & $.000 *$ \\
\hline & Within Groups & 231.942 & 286 & .811 & & \\
\hline & Total & 244.469 & 287 & & & \\
\hline \multirow[t]{3}{*}{ Leaders Have Integrity } & Between Groups & .022 & 1 & .022 & .057 & .811 \\
\hline & Within Groups & 107.756 & 286 & .377 & & \\
\hline & Total & 107.778 & 287 & & & \\
\hline \multirow[t]{3}{*}{ Fair Leaders } & Between Groups & .065 & 1 & .065 & .764 & .383 \\
\hline & Within Groups & 24.404 & 286 & .085 & & \\
\hline & Total & 24.469 & 287 & & & \\
\hline \multirow[t]{3}{*}{ Honest Leaders } & Between Groups & .012 & 1 & .012 & .144 & .705 \\
\hline & Within Groups & 24.817 & 286 & .087 & & \\
\hline & Total & 24.830 & 287 & & & \\
\hline \multirow[t]{3}{*}{ Trustworthy Leaders } & Between Groups & .011 & 1 & .011 & .117 & .732 \\
\hline & Within Groups & 26.853 & 285 & .094 & & \\
\hline & Total & 26.864 & 286 & & & \\
\hline
\end{tabular}

The Mean and Standard Deviation values in terms of the East and West part are also seen on the table below (See Table 6).

Table 6. Mean and SD Table of Spiritual Leadership Preferences in the East and West

\begin{tabular}{|ll|r|r|r|r|r|r|r|r|}
\hline West East & Humility & Respect & Ethical & Faith & Integrity & Fairness & Honesty & Trustworthy \\
\hline West & Mean & 4.7471 & 4.9070 & 4.8663 & 4.5097 & 4.7811 & 4.9186 & 4.9181 & 4.9012 \\
& Std. Deviation & .44935 & .29131 & .35807 & .68725 & .45578 & .27424 & .29559 & .29931 \\
\hline East & Mean & 4.6842 & 4.8621 & 4.7845 & 4.7434 & 4.7586 & 4.8966 & 4.8879 & 4.8793 \\
& Std. Deviation & .52065 & .34632 & .43351 & .51372 & .44955 & .30586 & .31682 & .32718 \\
\hline \multirow{2}{*}{ Total } & Mean & 4.7218 & 4.8889 & 4.8333 & 4.6082 & 4.7719 & 4.9097 & 4.9059 & 4.8924 \\
& Std. Deviation & .47934 & .31482 & .39155 & .62967 & .45260 & .28708 & .30417 & .31046 \\
\hline
\end{tabular}


In addition, a chi-square test of independence is performed to examine the relation between leaders who have faith and the people's expectations in the East and West part of Turkey. The relation between these variables is significant X2 $(4, \mathrm{~N}=288)=15.663$,

$p=0.004$. People in the East part of Turkey are more likely to support leaders who have faith than are people in the West part of Turkey (See Table 7).

Table 7. Chi-Square Tests Table of Faith

\begin{tabular}{lccr}
\hline & Value & df & $\begin{array}{c}\text { Asymp. Sig. } \\
\text { (2-sided) }\end{array}$ \\
\hline Pearson Chi-Square & $15.663^{\mathrm{a}}$ & 4 & $.004^{*}$ \\
Likelihood Ratio & 17.459 & 4 & $.002^{*}$ \\
Linear-by-Linear & 14.706 & 1 & $.000^{*}$ \\
Association & & & \\
N of Valid Cases & 288 & & \\
\hline a. 2 cells (20.0\%) have expected count less than 5. The minimum expected count is 1.21.
\end{tabular}

This difference can be seen in chi-square cross tabulation analysis. For example, while expected count for faith in the Eastern part is 74.5 strongly agree the count is 89 strongly agree. However, in the West part while the expected count is 110.5 strongly agree, the count is 96 strongly agree. On the other hand, while expected count for faith in the East part is 1.2 strongly disagree the count is 0 strongly disagree. However, in the West part while the expected count is 3.0 strongly disagree, the count is 3 strongly disagree (See Table 8 ).

Table 8. Cross-tabulation Table of Preferences of People Living in the East and West Part of Turkey in terms of Leaders Who Have Faith

\begin{tabular}{|c|c|c|c|c|c|c|c|c|}
\hline & & & \multicolumn{5}{|c|}{ Leaders should have faith } & \multirow[b]{2}{*}{ Total } \\
\hline & & & Strongly disagree & Disagree & Neutral & Agree & Strongly agree & \\
\hline \multirow[t]{6}{*}{ Regions of Turkey } & West & Count & 3 & 13 & 17 & 43 & 96 & 172 \\
\hline & & Expected & 1.8 & 9.6 & 12.5 & 37.6 & 110.5 & 172.0 \\
\hline & & Count & & & & & & \\
\hline & East & Count & 0 & 3 & 4 & 20 & 89 & 116 \\
\hline & & Expected & 1.2 & 6.4 & 8.5 & 25.4 & 74.5 & 116.0 \\
\hline & & Count & & & & & & \\
\hline \multirow[t]{3}{*}{ Total } & & Count & 3 & 16 & 21 & 63 & 185 & 288 \\
\hline & & Expected & 3.0 & 16.0 & 21.0 & 63.0 & 185.0 & 288.0 \\
\hline & & Count & & & & & & \\
\hline
\end{tabular}

Also, rankings of dimensions' participants rated in the Survey, which constitute spiritual leadership values are shown below in Table 9. 
Table 9. Percentages Table of Spirituality Dimensions in Spirituality

\begin{tabular}{|l|l|l|l|l|}
\hline \multicolumn{2}{|l|}{ EAST } & \multirow{2}{l}{ WEST } \\
\cline { 1 - 2 } Spimensions of & \multirow{2}{*}{ Percentage } & & Dimensions of & Percentage \\
\cline { 5 - 5 } 1-Fairness & $\% 22.19$ & & Spirituality & \\
\hline 2-Honesty & $\% 19.58$ & & 2- Fairness & $\% 18.34$ \\
\hline 3-Trustworthy & $\% 13.05$ & & 3- Trustworthy & $\% 14.46$ \\
\hline 4-Faith & $\% 11.22$ & 4- Respect & $\% 13.58$ \\
\hline 5-Ethic & $\% 10.96$ & & 5- Ethic & $\% 10.75$ \\
\hline 6-Respect & $\% 7.83$ & 6- Faith & $\% 10.58$ \\
\hline 7-Integrity & $\% 7.83$ & 7-Humility & $\% 5.99$ \\
\hline 8-Humility & $\% 7.31$ & 8- Integrity & $\% 5.11$ \\
\hline
\end{tabular}

According to Table 9, in the West part of Turkey faith is the sixth most preferred spiritual leadership value while it is the fourth most preferred spiritual leadership value in the East part of Turkey.

1-b. Secular Leaders: A one-way ANOVA is conducted to compare participants' preferences for the effect of secular leaders on people in the East part and the West part of Turkey. There is no significant difference in preferences for secular leaders in the East part and the West part of Turkey at the critical alpha level of .05 for the two conditions $F(1,284)=0.843, p=0.359$ $(\mathrm{M}=3.6, \mathrm{SD}=0.028)($ See Table 10).

Table 10. ANOVA Table of Preferences of Participants in terms of Secular Leaders

Secular Leaders

\begin{tabular}{|c|c|c|c|c|c|}
\hline & $\begin{array}{l}\text { Sum of } \\
\text { Squares }\end{array}$ & $\mathrm{df}$ & $\begin{array}{c}\text { Mean } \\
\text { Square }\end{array}$ & $\mathrm{F}$ & Sig. \\
\hline Between & 1.499 & 1 & 1.499 & .843 & .359 \\
\hline \multicolumn{6}{|l|}{ Groups } \\
\hline Within Groups & 504.854 & 284 & 1.778 & & \\
\hline Total & 506.353 & 285 & & & \\
\hline
\end{tabular}


A chi-square test of independence is performed to examine the relation between secular leaders and the people's expectations in the East and West part of Turkey. The relation between these variables is not significant $\mathrm{X} 2(4, \mathrm{~N}=286)=1.227, \mathrm{p}=0.874$. People in both the East part of Turkey and West part of Turkey are likely to show similar interest in secular leaders (See Table 11).

Table 11. Chi-Square Tests Table of Preferences of Participants in terms of Secular Leaders

\begin{tabular}{lccc}
\hline & Value & df & $\begin{array}{c}\text { Asymp. Sig. } \\
\text { (2-sided) }\end{array}$ \\
\hline Pearson Chi-Square & $1.227^{\mathrm{a}}$ & 4 & .874 \\
Likelihood Ratio & 1.223 & 4 & .874 \\
Linear-by-Linear & .844 & 1 & .358 \\
Association & & & \\
N of Valid Cases & 286 & & \\
\hline
\end{tabular}

0 cells $(.0 \%)$ have expected count less than 5 . The minimum expected count is 12.17 .

This difference can be seen in chi-square cross-tabulation analysis. For instance, while 37.7 strongly agree in an expected count for secular leaders in the Eastern region the actual count is 35 strongly agree. However, in the West part while the expected count is 55.3 strongly agree, the count is 58 strongly agree. On the other side, while expected count for secular leaders in the East part is 12.2 strongly disagree the count is 13 strongly disagree (See Table 12).

Table 12. Cross-tabulation Table of Preferences of People Living in the East and West Part of Turkey in terms of Secular Leaders

\begin{tabular}{|c|c|c|c|c|c|c|c|c|}
\hline & & & & Secul & ar Leade & & & \\
\hline & & & Strongly & & & & Strongly & \\
\hline & & & Disagree & Disagr. & Neutr. & Agree & Agree & Total \\
\hline Region of Turkey & West & Count & 17 & 20 & 24 & 51 & 58 & 170 \\
\hline & & Expected & 17.8 & 21.4 & 26.2 & 49.3 & 55.3 & 170.0 \\
\hline & & Count & & & & & & \\
\hline & East & Count & 13 & 16 & 20 & 32 & 35 & 116 \\
\hline & & Expected & 12.2 & 14.6 & 17.8 & 33.7 & 37.7 & 116.0 \\
\hline & & Count & & & & & & \\
\hline Total & & Count & 30 & 36 & 44 & 83 & 93 & 286 \\
\hline & & Expected & 30.0 & 36.0 & 44.0 & 83.0 & 93.0 & 286.0 \\
\hline & & Count & & & & & & \\
\hline
\end{tabular}

1-c. Religious Leaders: A one-way analysis of variance ANOVA is also utilized to compare the ranking of religious leaders by survey in the East and West part of Turkey. There is a significant difference between East part and West part of Turkey with respect to how the participants ranked religious leaders at the $p<0.05$ level for the two conditions $F(1,286)=$ $10.998, \mathrm{p}=0.001 .(\mathrm{M}=4.1, \mathrm{SD}=0.021)($ See Table 13$)$. 
Table 13. ANOVA Table of Preferences of Participants in terms of Religious Leaders

\begin{tabular}{|c|c|c|c|c|c|c|}
\hline & & $\begin{array}{l}\text { Sum of } \\
\text { Squares }\end{array}$ & df & $\begin{array}{l}\text { Mean } \\
\text { Square }\end{array}$ & $\mathrm{F}$ & Sig. \\
\hline Leaders Have & Between & 12.919 & 1 & 12.919 & 10.998 & $.001^{*}$ \\
\hline \multirow[t]{3}{*}{ Religiosity } & Groups & & & & & \\
\hline & Within Groups & 335.956 & 286 & 1.175 & & \\
\hline & Total & 348.875 & 287 & & & \\
\hline \multirow{4}{*}{$\begin{array}{l}\text { Pray Five Times A } \\
\text { Day }\end{array}$} & Between & 31.473 & 1 & 31.473 & 24.559 & $.000^{*}$ \\
\hline & Groups & & & & & \\
\hline & Within Groups & 366.513 & 286 & 1.282 & & \\
\hline & Total & 397.986 & 287 & & & \\
\hline \multirow{4}{*}{$\begin{array}{l}\text { Leaders Fast In } \\
\text { Ramadan }\end{array}$} & Between & 36.279 & 1 & 36.279 & 30.898 & $.000 *$ \\
\hline & Groups & & & & & \\
\hline & Within Groups & 334.634 & 285 & 1.174 & & \\
\hline & Total & 370.913 & 286 & & & \\
\hline \multirow{4}{*}{$\begin{array}{l}\text { Awareness Of } \\
\text { Halal And Haram }\end{array}$} & Between & 2.812 & 1 & 2.812 & 10.738 & $.001 *$ \\
\hline & Groups & & & & & \\
\hline & Within Groups & 74.906 & 286 & .262 & & \\
\hline & Total & 77.719 & 287 & & & \\
\hline \multirow{4}{*}{$\begin{array}{l}\text { Leaders Not To } \\
\text { Drink Alcohol }\end{array}$} & Between & 13.342 & 1 & 13.342 & 9.093 & $.003 *$ \\
\hline & Groups & & & & & \\
\hline & Within Groups & 419.654 & 286 & 1.467 & & \\
\hline & Total & 432.997 & 287 & & & \\
\hline \multirow{4}{*}{$\begin{array}{l}\text { Leaders Attend To } \\
\text { Friday Pray }\end{array}$} & Between & 24.657 & 1 & 24.657 & 19.734 & $.000 *$ \\
\hline & Groups & & & & & \\
\hline & Within Groups & 354.840 & 284 & 1.249 & & \\
\hline & Total & 379.497 & 285 & & & \\
\hline
\end{tabular}

A chi-square test of independence is performed to examine the relation between religious leaders and the people's expectations in the East and West part of Turkey. The relation between these variables significant X2 $(4, \mathrm{~N}=288)=19.349, \mathrm{p}=0.001$. The level of significance in the East part of Turkey who rated religious leaders are more than in the West of Turkey who rated religious leaders (See Table 14). 
Table 14. Chi-Square Tests Table of references of Participants in terms of Religious Leaders

\begin{tabular}{lccr} 
& Value & df & Asymp. Sig. (2-sided) \\
\hline Pearson & $19.349^{\mathrm{a}}$ & 4 & $.001^{*}$ \\
Chi-Square & & & \\
Likelihood Ratio & 19.947 & 4 & $.001^{*}$ \\
Linear-by-Linear & 10.628 & 1 & $.001^{*}$ \\
Association & & & \\
& & & \\
N of Valid Cases & 288 & & \\
\hline
\end{tabular}

a. 1 cells $(10.0 \%)$ have expected count less than 5 . The minimum expected count is 4.03

In the East part of Turkey, ratings of preference for religious leaders are higher than the ratings in the West part of Turkey. This difference can be seen in chi-square cross-tabulation analysis. For example, while expected count for religiosity in the East part is 55.6 strongly agree, the count is 73 strongly agree. However, in the West part while the expected count is 82.4 strongly agree, the count is 65 strongly agree (See Table 15).

Table 15. Cross-tabulation Table of Preferences of People Living in the East and West Part of Turkey in terms of Religious Leaders

\begin{tabular}{|c|c|c|c|c|c|c|c|c|}
\hline & & & \multicolumn{5}{|c|}{ Leaders Have Religiosity } & \multirow[b]{2}{*}{ Total } \\
\hline & & & strongly disagree & disagree & neutral & agree & strongly agree & \\
\hline \multirow[t]{4}{*}{ Regions of Turkey } & West & Count & 7 & 15 & 26 & 59 & 65 & 172 \\
\hline & & Expected Count & 6.0 & 13.7 & 19.1 & 50.8 & 82.4 & 172.0 \\
\hline & East & Count & 3 & 8 & 6 & 26 & 73 & 116 \\
\hline & & Expected Count & 4.0 & 9.3 & 12.9 & 34.2 & 55.6 & 116.0 \\
\hline \multirow[t]{2}{*}{ Total } & & Count & 10 & 23 & 32 & 85 & 138 & 288 \\
\hline & & Expected Count & 10.0 & 23.0 & 32.0 & 85.0 & 138.0 & 288.0 \\
\hline
\end{tabular}

2-Findings of Second Section of Questionnaire: In the second section of the questionnaire, people are asked to rank the most important seven characteristics that they would like to see in a leader in accordance with the survey questionnaire. However, they are not restricted within the scope of the survey questionnaire. People are free to respond with their own answers and add other characteristics and dimensions not mentioned in the survey. By doing this, the researcher aimed to find out the most important seven leadership characteristics and values that people want to see in a leader. A chi square test is conducted to analyze the results.

2-a. Ranking 1: A chi square test of independence is performed to examine the relation between the most preferred leadership characteristics, values, and expectations of people in the East part and the West part of Turkey. The difference between the East part and the West part of Turkey 
in terms of these variables is not significant at the $\mathrm{X} 2(8, \mathrm{~N}=287)=12.705, \mathrm{p}=0.122$. Citizens in both the West part and the East part of Turkey are likely to expect similar values and characteristics in their leaders (See Table 16).

Table 16. Chi Square Tests Table of Ranking 1

\begin{tabular}{lrcc}
\hline & Value & df & $\begin{array}{c}\text { Asymp. Sig. } \\
\text { (2-sided) }\end{array}$ \\
\hline Pearson Chi-Square & $12.705^{\mathrm{a}}$ & 8 & .122 \\
Likelihood Ratio & 14.470 & 8 & .070 \\
Linear-by-Linear & .460 & 1 & .498 \\
Association & & & \\
N of Valid Cases & 287 & & \\
\hline
\end{tabular}

a. 8 cells $(44.4 \%)$ have expected count less than 5 . The minimum expected count is .81 .

Both in the West and in the East part of Turkey, spirituality is the most and preferred value people want to see in a leader. While religious values is fourth most preferred leadership value in the West part of Turkey (See Table 17).

Table 17. Cross-tabulation Table of Ranking 1

\begin{tabular}{|c|c|c|c|c|c|}
\hline & & & \multicolumn{2}{|c|}{ East and West of Turkey } & \multirow[b]{2}{*}{ Total } \\
\hline & & & West & East & \\
\hline \multirow{18}{*}{$\begin{array}{l}\text { Sprtl,Rlgs,Nrmtv,Econm,S } \\
\text { clr,Other }\end{array}$} & \multirow{2}{*}{ Spiritual Values } & Count & 109 & 77 & 186 \\
\hline & & Expected Count & 110.8 & 75.2 & 186.0 \\
\hline & \multirow[t]{2}{*}{ Religious Values } & Count & 8 & 13 & 21 \\
\hline & & Expected Count & 12.5 & 8.5 & 21.0 \\
\hline & \multirow[t]{2}{*}{ Normative Values } & Count & 26 & 7 & 33 \\
\hline & & Expected Count & 19.7 & 13.3 & 33.0 \\
\hline & \multirow[t]{2}{*}{ Economy } & Count & 7 & 7 & 14 \\
\hline & & Expected Count & 8.3 & 5.7 & 14.0 \\
\hline & \multirow[t]{2}{*}{ Secular } & Count & 2 & 0 & 2 \\
\hline & & Expected Count & 1.2 & .8 & 2.0 \\
\hline & \multirow[t]{2}{*}{ Charisma } & Count & 4 & 3 & 7 \\
\hline & & Expected Count & 4.2 & 2.8 & 7.0 \\
\hline & \multirow[t]{2}{*}{ Good Politician } & Count & 3 & 3 & 6 \\
\hline & & Expected Count & 3.6 & 2.4 & 6.0 \\
\hline & \multirow[t]{2}{*}{ Conflict Resolution } & Count & 2 & 0 & 2 \\
\hline & & Expected Count & 1.2 & .8 & 2.0 \\
\hline & \multirow[t]{2}{*}{ Educated } & Count & 10 & 6 & 16 \\
\hline & & Expected Count & 9.5 & 6.5 & 16.0 \\
\hline \multirow[t]{2}{*}{ Total } & & Count & 171 & 116 & 287 \\
\hline & & Expected Count & 171.0 & 116.0 & 287.0 \\
\hline
\end{tabular}




\section{Macrothink

Secularity is the least preferred leadership value both in the West and in East part of Turkey in the 1st ranking. However, there is still some insignificant difference between the East and the West part in terms of expected and observed counts (See Table 17).

2-b. Ranking 2: A chi-square test of independence is performed to examine the relation between most preferred leadership values and characteristics and expectations of the people in the East and West part of Turkey. The relation between these variables is not significant X2 (8, $\mathrm{N}=287)=15.451, \mathrm{p}=.051$. People both in the West part of Turkey and in East part of Turkey are likely to prefer similar values and characteristics in leaders (See Table 18).

Table 18. Chi Square Test Table of Ranking 2

\begin{tabular}{lrrr}
\hline & \multicolumn{2}{c}{$\begin{array}{c}\text { Asymp. Sig. } \\
\text { (2-sided) }\end{array}$} \\
\hline Palue & \multicolumn{1}{c}{ df } & \multicolumn{1}{c}{851} \\
Likelihood Ratio & $15.451^{\mathrm{a}}$ & 8 & .618 \\
Linear-by-Linear & 1.540 & 1 & .034 \\
Association & & & .215 \\
N of Valid Cases & 287 & & \\
\hline
\end{tabular}

a. 10 cells $(55.6 \%)$ have expected count less than 5 . The minimum expected count is .81 .

Although secularity is still the least preferred leadership value people wanted to see in leaders in the East part of Turkey, it is the fourth most preferred leadership value people want to see in the West part of Turkey. This insignificant difference can be seen in chi-square cross-tabulation analysis in Table 19. 
Table 19. Cross-tabulation Table of Ranking 2

\begin{tabular}{|c|c|c|c|c|c|}
\hline & & & \multicolumn{2}{|c|}{$\begin{array}{c}\text { East and West of } \\
\text { Turkey }\end{array}$} & \multirow[b]{2}{*}{ Total } \\
\hline & & & West & East & \\
\hline \multirow{27}{*}{$\begin{array}{l}\text { Sprtl,Rlgs,Nrmtv,E } \\
\text { conm,Sclr,Other }\end{array}$} & Spiritual & Count & 121 & 70 & 191 \\
\hline & & Expected & 113.8 & 77.2 & 191.0 \\
\hline & & Count & & & \\
\hline & Religious & Count & 14 & 19 & 33 \\
\hline & & Expected & 19.7 & 13.3 & 33.0 \\
\hline & & Count & & & \\
\hline & Normative & Count & 7 & 4 & 11 \\
\hline & & Expected & 6.6 & 4.4 & 11.0 \\
\hline & & Count & & & \\
\hline & Economy & Count & 11 & 11 & 22 \\
\hline & & Expected & 13.1 & 8.9 & 22.0 \\
\hline & & Count & & & \\
\hline & Secular & Count & 8 & 1 & 9 \\
\hline & & Expected & 5.4 & 3.6 & 9.0 \\
\hline & & Count & & & \\
\hline & Charisma & Count & 3 & 1 & 4 \\
\hline & & Expected & 2.4 & 1.6 & 4.0 \\
\hline & & Count & & & \\
\hline & Good Politician & Count & 3 & 5 & 8 \\
\hline & & Expected & 4.8 & 3.2 & 8.0 \\
\hline & & Count & & & \\
\hline & Conflict & Count & 2 & 0 & 2 \\
\hline & Resolution & Expected & 1.2 & .8 & 2.0 \\
\hline & & Count & & & \\
\hline & Educated & Count & 2 & 5 & 7 \\
\hline & & Expected & 4.2 & 2.8 & 7.0 \\
\hline & & Count & & & \\
\hline \multirow[t]{3}{*}{ Total } & & Count & 171 & 116 & 287 \\
\hline & & Expected & 171.0 & 116.0 & 287.0 \\
\hline & & Count & & & \\
\hline
\end{tabular}

2-c. Ranking 3: A chi-square test of independence is performed to examine the relation between most preferred leadership values and characteristics, and expectations of the people in the East and West part of Turkey. The relation between these variables is not significant X2 (8, $\mathrm{N}=287)=13.387, \mathrm{p}=0.099$. People in both the East part of Turkey and East part of Turkey are 


\section{Macrothink

likely to prefer similar values and characteristics in leaders (See Table 20).

Table 20. Chi-Square Tests Table of Ranking 3

\begin{tabular}{lrrr}
\hline & \multicolumn{2}{c}{$\begin{array}{c}\text { Asymp. Sig. } \\
\text { (2-sided) }\end{array}$} \\
\hline Pearson Chi-Square & $13.387^{\mathrm{a}}$ & 8 & .099 \\
Likelihood Ratio & 14.105 & 8 & .079 \\
Linear-by-Linear & 2.616 & 1 & .106 \\
Association & & & \\
N of Valid Cases & 287 & & \\
\hline
\end{tabular}

In this 3rd ranking, like 2nd ranking, however unlike the 1st ranking, both in the West and in the East part of Turkey, religious values is the second most preferred leadership value while spirituality is the most preferred leadership value people want to see in a leader. However, there is still some insignificant difference between the East and the West part in terms of expected and observed counts (See Table 21). 
Table 21. Cross-tabulation Table of Ranking 3

\begin{tabular}{|c|c|c|c|c|c|}
\hline & & & \multicolumn{2}{|c|}{$\begin{array}{c}\text { East and West of } \\
\text { Turkey }\end{array}$} & \multirow[b]{2}{*}{ Total } \\
\hline & & & West & East & \\
\hline \multirow{18}{*}{$\begin{array}{l}\text { Sprtl,Rlgs,Nrmtv,Ec } \\
\text { onm,Sclr,Other }\end{array}$} & Spiritual & Count & 98 & 62 & 160 \\
\hline & & Expected Count & 95.3 & 64.7 & 160.0 \\
\hline & Religious & Count & 22 & 20 & 42 \\
\hline & & Expected Count & 25.0 & 17.0 & 42.0 \\
\hline & Normative & Count & 13 & 2 & 15 \\
\hline & & Expected Count & 8.9 & 6.1 & 15.0 \\
\hline & Economy & Count & 10 & 5 & 15 \\
\hline & & Expected Count & 8.9 & 6.1 & 15.0 \\
\hline & Secular & Count & 10 & 3 & 13 \\
\hline & & Expected Count & 7.7 & 5.3 & 13.0 \\
\hline & Charisma & Count & 4 & 5 & 9 \\
\hline & & Expected Count & 5.4 & 3.6 & 9.0 \\
\hline & Good Politician & Count & 3 & 2 & 5 \\
\hline & & Expected Count & 3.0 & 2.0 & 5.0 \\
\hline & Conflict & Count & 4 & 5 & 9 \\
\hline & Resolution & Expected Count & 5.4 & 3.6 & 9.0 \\
\hline & Educated & Count & 7 & 12 & 19 \\
\hline & & Expected Count & 11.3 & 7.7 & 19.0 \\
\hline \multirow[t]{2}{*}{ Total } & & Count & 171 & 116 & 287 \\
\hline & & Expected Count & 171.0 & 116.0 & 287.0 \\
\hline
\end{tabular}

On the other hand, secularity is still less preferred leadership value people wanted to see in leaders in the East part of Turkey. While secularity is the third least preferred leadership value in the East part of Turkey, it is the fourth most preferred leadership value people want to see in the West part of Turkey (See Table 21). 


\section{Macrothink}

Journal of Management Research

ISSN 1941-899X 2019, Vol. 11, No. 4

2-d. Ranking 4: A chi-square test of independence is performed to examine the relation between most preferred leadership values and characteristics, and expectations of the people in the East and West part of Turkey. The relation between these variables is not significant X2 (8, $\mathrm{N}=284)=6.942, \mathrm{p}=0.543$. People both in the East part of Turkey and in East part of Turkey are likely to prefer similar values and characteristics in leaders (See Table 22).

Table 22. Chi-Square Tests Table of Ranking 4

\begin{tabular}{lrrr}
\hline & & & \multicolumn{2}{c}{ Asymp. } \\
& Value & df & Sig. (2-sided) \\
\hline Pearson Chi-Square & $6.942^{\mathrm{a}}$ & 8 & .543 \\
Likelihood Ratio & 7.659 & 8 & .467 \\
Linear-by-Linear Association & .061 & 1 & .805 \\
N of Valid Cases & 284 & & \\
\hline
\end{tabular}

a. 6 cells $(33.3 \%)$ have expected count less than 5 . The minimum expected count is 3 .

In this 4th ranking, like 2nd and 3rd ranking and unlike the 1st ranking, both in the West and the East part religious values is the second most preferred leadership value while spirituality is the most preferred leadership value people want to see in a leader. However, there is still some insignificant difference between the East and the West parts in terms of expected and observed counts (See Table 23). 
Table 23. Cross-tabulation Table of Ranking 4

\begin{tabular}{|c|c|c|c|c|c|}
\hline & & & \multicolumn{2}{|c|}{$\begin{array}{c}\text { East and West of } \\
\text { Turkey }\end{array}$} & \multirow[b]{2}{*}{ Total } \\
\hline & & & West & East & \\
\hline \multirow{13}{*}{$\begin{array}{l}\text { Sprtl,Rlgs,Nrmtv, } \\
\text { Econm,Sclr,Othe } \\
\text { r }\end{array}$} & Spiritual & Count & 81 & 56 & 137 \\
\hline & & Expected & 81.5 & 55.5 & 137.0 \\
\hline & & Count & & & \\
\hline & Religious & Count & 23 & 21 & 44 \\
\hline & & $\begin{array}{l}\text { Expected } \\
\text { Count }\end{array}$ & 26.2 & 17.8 & 44.0 \\
\hline & Normative & Count & 13 & 2 & 15 \\
\hline & & $\begin{array}{l}\text { Expected } \\
\text { Count }\end{array}$ & 8.9 & 6.1 & 15.0 \\
\hline & Economy & Count & 17 & 10 & 27 \\
\hline & & $\begin{array}{l}\text { Expected } \\
\text { Count }\end{array}$ & 16.1 & 10.9 & 27.0 \\
\hline & Secular & Count & 5 & 3 & 8 \\
\hline & & $\begin{array}{l}\text { Expected } \\
\text { Count }\end{array}$ & 4.8 & 3.2 & 8.0 \\
\hline & Charisma & Count & 8 & 4 & 12 \\
\hline & & $\begin{array}{l}\text { Expected } \\
\text { Count }\end{array}$ & 7.1 & 4.9 & 12.0 \\
\hline
\end{tabular}

On the other hand, secularity is one of the least wanted leadership value in both the East part and the West part of Turkey. However, there is still some insignificant difference between the East and the West part in terms of expected and observed counts. For example, while expected count for secular values is 3.2 count is 3 in the East part, expected count is 4.8 count is 5 in the West part of Turkey (See Table 24). 
Table 24. Cross-tabulation Table of Ranking 4

\begin{tabular}{|c|c|c|c|c|c|}
\hline & & & \multicolumn{2}{|c|}{$\begin{array}{c}\text { East and West of } \\
\text { Turkey }\end{array}$} & \multirow[b]{2}{*}{ Total } \\
\hline & & & West & East & \\
\hline \multirow{27}{*}{$\begin{array}{l}\text { Sprtl,Rlgs,Nrmtv, } \\
\text { Econm,Sclr,Othe } \\
\text { r }\end{array}$} & Spiritual & Count & 81 & 56 & 137 \\
\hline & & Expected & 81.5 & 55.5 & 137.0 \\
\hline & & Count & & & \\
\hline & Religious & Count & 23 & 21 & 44 \\
\hline & & Expected & 26.2 & 17.8 & 44.0 \\
\hline & & Count & & & \\
\hline & Normative & Count & 13 & 2 & 15 \\
\hline & & Expected & 8.9 & 6.1 & 15.0 \\
\hline & & Count & & & \\
\hline & Economy & Count & 17 & 10 & 27 \\
\hline & & Expected & 16.1 & 10.9 & 27.0 \\
\hline & & Count & & & \\
\hline & Secular & Count & 5 & 3 & 8 \\
\hline & & Expected & 4.8 & 3.2 & 8.0 \\
\hline & & Count & & & \\
\hline & Charisma & Count & 8 & 4 & 12 \\
\hline & & Expected & 7.1 & 4.9 & 12.0 \\
\hline & & Count & & & \\
\hline & Good Polit & Count & 6 & 5 & 11 \\
\hline & & Expected & 6.5 & 4.5 & 11.0 \\
\hline & & Count & & & \\
\hline & Conflict & Count & 5 & 3 & 8 \\
\hline & Resolution & Expected & 4.8 & 3.2 & 8.0 \\
\hline & & Count & & & \\
\hline & Educated & Count & 11 & 11 & 22 \\
\hline & & Expected & 13.1 & 8.9 & 22.0 \\
\hline & & Count & & & \\
\hline Total & & Count & 169 & 115 & 284 \\
\hline & & Expected & 169.0 & 115.0 & 284.0 \\
\hline & & Count & & & \\
\hline
\end{tabular}

2-e. Ranking 5: A chi-square test of independence is performed to examine the relation between most preferred leadership values and characteristics, and expectations of the people in the East and West part of Turkey. The relation between these variables is not significant X2 (8, $\mathrm{N}=277)=15.437, \mathrm{p}=0.051$. People in both the East part of Turkey and East part of Turkey are likely to prefer similar values and characteristics in leaders (See Table 25). 
Table 25. Chi-Square Tests Table of Ranking 5

\begin{tabular}{lrrr}
\hline & \multicolumn{3}{c}{$\begin{array}{c}\text { Asymp. Sig. } \\
\text { (2-sided) }\end{array}$} \\
\hline Pearson Chi-Square & $15.437^{\mathrm{a}}$ & 8 & .051 \\
Likelihood Ratio & 15.465 & 8 & .051 \\
Linear-by-Linear & .196 & 1 & .658 \\
Association & & & \\
N of Valid Cases & 277 & & \\
\hline
\end{tabular}

In this 5th ranking, unlike 2nd, 3rd, and 4th ranking, and like the 1 st ranking, there is an insignificant difference in terms of religion. Both in the West and in the East part of Turkey, spirituality is the most preferred leadership value people want to see in a leader. Although in the West part fixing the economy is the second most preferred leadership value people want to see in a leader, in the East part of Turkey religious values is the most preferred second leadership value people want to see in a leader. While "religious values" is fourth most preferred leadership value in the West part of Turkey, it is second most preferred leadership value that people want to see after spiritual values in the East part of Turkey (See Table 26). 
Table 26. Cross-tabulation Table of Ranking 5

\begin{tabular}{|c|c|c|c|c|c|}
\hline & & & \multicolumn{2}{|c|}{$\begin{array}{c}\text { East and West of } \\
\text { Turkey }\end{array}$} & \multirow[b]{2}{*}{ Total } \\
\hline & & & West & East & \\
\hline Sprtl,Rlgs,Nrmtv, & Spiritual & Count & 90 & 53 & 143 \\
\hline \multirow[t]{17}{*}{ Econm,Sclr,Other } & & $\begin{array}{l}\text { Expected } \\
\text { Count }\end{array}$ & 85.2 & 57.8 & 143.0 \\
\hline & Religious & Count & 11 & 24 & 35 \\
\hline & & $\begin{array}{l}\text { Expected } \\
\text { Count }\end{array}$ & 20.8 & 14.2 & 35.0 \\
\hline & Normative & Count & 10 & 7 & 17 \\
\hline & & $\begin{array}{l}\text { Expected } \\
\text { Count }\end{array}$ & 10.1 & 6.9 & 17.0 \\
\hline & Economy & Count & 17 & 7 & 24 \\
\hline & & $\begin{array}{l}\text { Expected } \\
\text { Count }\end{array}$ & 14.3 & 9.7 & 24.0 \\
\hline & Secular & Count & 6 & 3 & 9 \\
\hline & & $\begin{array}{l}\text { Expected } \\
\text { Count }\end{array}$ & 5.4 & 3.6 & 9.0 \\
\hline & Charisma & Count & 5 & 1 & 6 \\
\hline & & $\begin{array}{l}\text { Expected } \\
\text { Count }\end{array}$ & 3.6 & 2.4 & 6.0 \\
\hline & Good Politi & Count & 8 & 5 & 13 \\
\hline & & $\begin{array}{l}\text { Expected } \\
\text { Count }\end{array}$ & 7.7 & 5.3 & 13.0 \\
\hline & Conflict & Count & 8 & 4 & 12 \\
\hline & Resolution & $\begin{array}{l}\text { Expected } \\
\text { Count }\end{array}$ & 7.1 & 4.9 & 12.0 \\
\hline & Educated & Count & 10 & 8 & 18 \\
\hline & & $\begin{array}{l}\text { Expected } \\
\text { Count }\end{array}$ & 10.7 & 7.3 & 18.0 \\
\hline \multirow[t]{2}{*}{ Total } & & Count & 165 & 112 & 277 \\
\hline & & $\begin{array}{l}\text { Expected } \\
\text { Count }\end{array}$ & 165.0 & 112.0 & 277.0 \\
\hline
\end{tabular}

On the other hand, secularity is one of the least preferred leadership value in both the East part and the West part of Turkey. However, there is still some insignificant difference between the East and the West part in terms of expected and observed counts. (See Table 26).

2-f. Ranking 6: A chi-square test is performed to examine the relation between most preferred leadership values and characteristics, and the people in the East and West part of Turkey. The relation between these variables is not significant $\mathrm{X} 2(8, \mathrm{~N}=269)=13.657, \mathrm{p}=0.091$. People, 


\section{Macrothink}

Journal of Management Research

ISSN 1941-899X

2019, Vol. 11, No. 4

both in the East part of Turkey and in East part of Turkey, are likely to prefer similar values and characteristics in leaders (See Table 27).

Table 27. Chi-Square Tests Table of Ranking 6

\begin{tabular}{lrrrr}
\hline & Value & df & Asymp. Sig. (2-sided) \\
\hline Pearson Chi-Square & $13.657^{\text {a }}$ & 8 & .091 \\
Likelihood Ratio & 16.060 & 8 & .042 \\
Linear-by-Linear & 2.389 & 1 & .122 \\
Association & & & \\
N of Valid Cases & 269 & & \\
\hline
\end{tabular}

a. 6 cells $(33.3 \%)$ have expected count less than 5 . The minimum expected count is 2.48 .

In this 6th ranking, unlike 2nd, 3rd, and 4th ranking, and like the 1st, 5th ranking, there is an insignificant difference in terms of religion. Both in the West and in the East part of Turkey, spirituality is the most preferred leadership value people want to see in a leader. Although in the West part fixing the economy is the second most preferred leadership value people want to see in a leader, in the East part of Turkey religious values is the most preferred second leadership value people want to see in a leader. While religious values is third most preferred leadership value in the West part of Turkey, it is second most preferred leadership value that people want to see in leaders in the East part of Turkey (See Table 28). 
Table 28. Cross-tabulation Table of Ranking 6

\begin{tabular}{|c|c|c|c|c|c|}
\hline & & & \multicolumn{2}{|c|}{$\begin{array}{c}\text { East and West of } \\
\text { Turkey }\end{array}$} & \multirow[b]{2}{*}{ Total } \\
\hline & & & West & East & \\
\hline \multirow{19}{*}{$\begin{array}{l}\text { Sprtl,Rlgs,Nrmtv, } \\
\text { Econm,Sclr,Othe } \\
\text { r }\end{array}$} & Spiritual & Count & 79 & 62 & 141 \\
\hline & & Expected & 82.8 & 58.2 & 141.0 \\
\hline & & Count & & & \\
\hline & Religious & Count & 15 & 16 & 31 \\
\hline & & $\begin{array}{l}\text { Expected } \\
\text { Count }\end{array}$ & 18.2 & 12.8 & 31.0 \\
\hline & Normative & Count & 9 & 5 & 14 \\
\hline & & $\begin{array}{l}\text { Expected } \\
\text { Count }\end{array}$ & 8.2 & 5.8 & 14.0 \\
\hline & Economy & Count & 22 & 11 & 33 \\
\hline & & $\begin{array}{l}\text { Expected } \\
\text { Count }\end{array}$ & 19.4 & 13.6 & 33.0 \\
\hline & Secular & Count & 6 & 0 & 6 \\
\hline & & $\begin{array}{l}\text { Expected } \\
\text { Count }\end{array}$ & 3.5 & 2.5 & 6.0 \\
\hline & Charisma & Count & 3 & 4 & 7 \\
\hline & & $\begin{array}{l}\text { Expected } \\
\text { Count }\end{array}$ & 4.1 & 2.9 & 7.0 \\
\hline & Good Politician & Count & 4 & 7 & 11 \\
\hline & & $\begin{array}{l}\text { Expected } \\
\text { Count }\end{array}$ & 6.5 & 4.5 & 11.0 \\
\hline & Conflict & Count & 8 & 2 & 10 \\
\hline & Resolution & $\begin{array}{l}\text { Expected } \\
\text { Count }\end{array}$ & 5.9 & 4.1 & 10.0 \\
\hline & Educated & Count & 12 & 4 & 16 \\
\hline & & $\begin{array}{l}\text { Expected } \\
\text { Count } \\
\end{array}$ & 9.4 & 6.6 & 16.0 \\
\hline \multirow[t]{2}{*}{ Total } & & Count & 158 & 111 & 269 \\
\hline & & $\begin{array}{l}\text { Expected } \\
\text { Count }\end{array}$ & 158.0 & 111.0 & 269.0 \\
\hline
\end{tabular}

2-g. Ranking 7: A chi-square test of independent is performed to examine the relation between most preferred leadership values and characteristics, and the people in the East and West part of Turkey. The relation between these variables is not significant $\mathrm{X} 2(8, \mathrm{~N}=259)=10.723$, $\mathrm{p}=.218$. People both in the West part of Turkey and in East part of Turkey are likely to prefer similar values and characteristics in leaders (See Table 29). 
Table 29. Chi-Square Tests Table of Ranking 7

\begin{tabular}{lccc}
\hline & Value & df & Asymp. Sig. (2-sided) \\
\hline Pearson Chi-Square & $10.723^{\text {a }}$ & 8 & .218 \\
Likelihood Ratio & 10.997 & 8 & .202 \\
Linear-by-Linear & 3.430 & 1 & .064 \\
Association & & & \\
N of Valid Cases & 259 & & \\
\hline
\end{tabular}

a. 4 cells $(22.2 \%)$ have expected count less than 5 . The minimum expected count is 2.50

In this 7 th ranking, unlike $2^{\text {nd }}, 3^{\text {rd, }}$ and $4^{\text {th }}$ ranking, and like the $1^{\text {st }}, 5^{\text {th }}$, and $6^{\text {th }}$ ranking, there is an insignificant difference in terms of religion. Both in the West and in the East part of Turkey, spirituality is the most preferred leadership value people want to see in a leader. Although in the West part "education" is the second, and fixing the economy is the third most preferred leadership values people want to see in a leader. In the East part of Turkey religious values is still the most preferred second leadership value people want to see in a leader. While religious values is fifth most preferred leadership value in the West part of Turkey, it is only second after spiritual values in the East part of Turkey (See Table 30). 
Table 30. Cross-tabulation Table of Ranking 7

\begin{tabular}{|c|c|c|c|c|c|}
\hline & & & ast and Wes & f Turkey & \\
\hline & & & West & East & Total \\
\hline Sprtl,Rlgs,Nrmtv,Eco & Spiritual & Count & 61 & 57 & 118 \\
\hline $\mathrm{nm}$,Sclr,Other & & Expected Count & 68.8 & 49.2 & 118.0 \\
\hline & Religious & Count & 12 & 11 & 23 \\
\hline & & Expected Count & 13.4 & 9.6 & 23.0 \\
\hline & Normative & Count & 4 & 2 & 6 \\
\hline & & Expected Count & 3.5 & 2.5 & 6.0 \\
\hline & Economy & Count & 17 & 9 & 26 \\
\hline & & Expected Count & 15.2 & 10.8 & 26.0 \\
\hline & Secular & Count & 8 & 2 & 10 \\
\hline & & Expected Count & 5.8 & 4.2 & 10.0 \\
\hline & Charisma & Count & 8 & 3 & 11 \\
\hline & & Expected Count & 6.4 & 4.6 & 11.0 \\
\hline & Good Politician & Count & 16 & 7 & 23 \\
\hline & & Expected Count & 13.4 & 9.6 & 23.0 \\
\hline & Conflict Resolutio & Count & 5 & 8 & 13 \\
\hline & & Expected Count & 7.6 & 5.4 & 13.0 \\
\hline & Educated & Count & 20 & 9 & 29 \\
\hline & & Expected Count & 16.9 & 12.1 & 29.0 \\
\hline Total & & Count & 151 & 108 & 259 \\
\hline & & Expected Count & 151.0 & 108.0 & 259.0 \\
\hline
\end{tabular}

After these explanations, an average of all these 7 rankings is measured and percentages of the average rankings are shown from the highest to the lowest (See Table 31). 
Table 31. An Average Ranking Table of the All Seven Rankings

\begin{tabular}{|l|l|l|l|l|}
\hline \multicolumn{2}{|l|}{ EAST } & & \multirow{2}{*}{ WEST } \\
\cline { 1 - 2 } Leadership & Percentage & & Leadership & \multirow{2}{*}{ Percentage } \\
\cline { 1 - 2 } 1-Spirituality & $\% 53.81$ & & Characteristics & \\
\hline 2-Religion & $\% 15.26$ & & 1-Spirituality & $\% 53.38$ \\
\hline 3-Economy & $\% 7.38$ & & 2-Religion & $\% 8.77$ \\
\hline 4-Education & $\% 6.76$ & & 3-Economy & $\% 8.43$ \\
\hline 5-Good Poltcn & $\% 4.18$ & & 4-Normative & $\% 6.84$ \\
\hline 6-Normative & $\% 3.56$ & & 5-Education & $\% 6.01$ \\
\hline 7-Conflict Rsit & $\% 2.70$ & & 6-Secularity & $\% 3.75$ \\
\hline 8-Charisma & $\% 2.58$ & 7-Good Poltcn & $\% 3.59$ \\
\hline 9-Secularity & $\% 1.47$ & 8-Charisma & $\% 2.92$ \\
\hline
\end{tabular}

Table 31 shows the spirituality is the most preferred leadership value people want to see in leaders both in the East part and in the West part of Turkey. Religion is the most preferred second leadership value people want to see in leaders both in the East part and in the West part of Turkey. However, people who expect leaders to have religious values are $15.26 \%$ in the East part of Turkey, while it is only $8.77 \%$ in the West part of Turkey. Therefore, a higher percentage of people in Turkey valued religiosity in their leader in the East part of than that of in the West part of Turkey.

On the other hand, secularity is the least preferred leadership value people want to see in leaders in the East part of Turkey with the percentage of only $1.47 \%$, while it is 6 th in the ranking with the $3.75 \%$ in the West part of Turkey

\section{Conclusion}

The study is set out to explore people's preferences and attitudes about spiritual leadership in Turkey and has identified the concepts of spiritual leadership, spirituality, faith, religion, and secularity. The study has also sought to identify whether there are similarities and differences between the East and West parts of Turkey in terms of people's expectations about spiritual 
leadership from leaders.

Expectations from leaders to have faith are higher in the East part of Turkey then in the West part. People in the East part of Turkey expect to see leaders who have faith more than people do in the West. However, in terms of the other dimensions of spirituality such as honesty, fairness, trustworthy, humility, integrity, ethics, and respect, both West and East part of Turkey had the same expectations. Thus, there is not a big difference between East and West part of Turkey in terms of having spiritual leaders, except for leaders having faith.

In the East part of Turkey, people prefer to see religious leaders more than the people in the West part of Turkey. When we compare the West part to the East part, the level of expectations to see religious leaders is less in the West part of Turkey then the East part of Turkey. Therefore, there is a difference between East and West part of Turkey in terms of having religious leaders. This expectation is higher in the East part of Turkey than the West part of Turkey.

People both in the East and West part of Turkey prefer to see leaders who have spiritual characteristics first. In the East part of Turkey, spirituality is the most preferred leadership value people expect to see in leaders. However, secularity is the least preferred or unwanted leadership value people wanted to see in a leader in the East part of Turkey. On the other hand, in the West part of Turkey, spirituality is the most preferred leadership value people expect to see in leaders. However, secularity is the least preferred leadership value people wanted to see in a leader in the West part of Turkey. Therefore, it is concluded that people in Turkey prefer spiritual leaders over non-spiritual leaders.

Majority of the participants preferred to see leaders who have spiritual values in both the West and East part of Turkey. On the other hand, religious values are listed in the second rank both in the West and in East part of Turkey. It is revealed that people in Turkey prefer spiritual leaders over religious leaders in Turkey.

These results can be implemented in training the high ranking government officials such as bureaucrats and district governors to empower them with spiritual leadership values and characteristics; so, they could provide better services for the benefit of the people. In addition, political parties can bring spiritual leadership values to their agenda. They can emphasize these values in their party programs and to raise awareness among the party leaders and members to inspire and sustain people.

\section{References}

Abbasi, A., Rehman, K., \& Bibi, A. (2010). Islamic leadership model an accountability perspective. World Applied Sciences Journal, 9(3), 230-238.

AlSarhi, N. Z., Lailawati, M. S., Mohamed, Z. A., \& Amini, A. A. (2014). The West And Islam Perspective of Leadership. International Affairs and Global Strategy, 18, 42-56. https://doi.org/10.1108/SL-08-2014-0057

Banks, R., \& Powell, K. (Eds.). (2000). Faith in leadership. San Francisco: Jossey Bass. 


\section{Macrothink}

Journal of Management Research ISSN 1941-899X 2019, Vol. 11, No. 4

Bates, S. (2002, March). Honesty, empathy cited in effective leadership. HR Magazine, 47(3).

Becker, T. (2000). Hallmarks and consequences of integrity in organizations: The employees' perspective. Paper presented at the Academy of Management Conference, Toronto, Ontario, August.

Bennis, W., \& O'Toole, J. (2000). Don't hire the wrong CEO. Harvard Business Review, $78(3), 170-176$.

Blackaby, H., \& Blackaby, R. (2001). Spiritual leadership. Nashville, TN: Broadman \& Holman.

Burton, M. D., \& O'Reilly, C. (2000). The impact of high commitment values and practices on technology start-ups. Unpublished paper, Sloan School of Management, Massachusetts Institute of Technology, Cambridge.

Cavanagh, G. F. (1999). Spirituality for managers: Context and critique. Journal of Organizational Change Management, $12(3)$, 124-134. https://doi.org/10.1108/09534819910273793

Clawson, J. G. (1999). Level Three Leadership: Getting below the Surface, Prentice-Hall, Upper Saddle River, NJ.

Dirks, K. T., \& Ferrin, D. L. (2002). Trust in leadership: Meta-analytic findings and implications for research and practice. Journal of Applied Psychology, 87(4), 611-628. https://doi.org/10.1037//0021-9010.87.4.611

Dorfman, P., Hanges, P. J., \& Brodbeck, F. C. (2004). Leadership and cultural variation: The identification of culturally endorsed leadership profiles, leadership, culture, and organizations: The GLOBE study of 62 societies. Thousand Oaks, CA7 Sage.

Eisler, R., \& Montouori, A. (2003). The human side of spirituality. In R. A. Giacalone, \& C. L.

Erturk, A. (2006). Increasing organizational citizenship behaviors of Turkish academicians: Mediating role of trust in supervisor on the relationship between organizational justice and citizenship behaviors. Journal of Managerial Psychology, 22(3), 257-270. https://doi.org/10.1108/02683940710733089

Fairholm, G. W. (1996). Spiritual leadership: fulfilling whole-self needs at work. Leadership \& Organization Development Journal, 17-17. https://doi.org/10.1108/01437739610127469

Fairholm, G. W. 1997. Capturing the heart of leadership: Spirituality and community in the new American workplace. Westport, CT: Praeger.

Fleenor, J. W., McCauley, C. D., \& Brutus, S. (1996). Self-other rating agreement and leader effectiveness. The Leadership Quarterly, 7(4), 487-506. https://doi.org/10.1016/S1048-9843(96)90003-X 


\section{MInstitute Macrothink}

Journal of Management Research

ISSN 1941-899X

2019, Vol. 11, No. 4

Freeman, G. T. (2011). Spirituality and Servant Leadership: A Conceptual Model and Research Proposal. Emerging Leadership Journeys, 4(10), 220-140.

Fry, L. W. (2003). Toward a theory of spiritual leadership. The Leadership Quarterly, 14, 693-727. https://doi.org/10.1016/j.leaqua.2003.09.001

Fry, L. W., Vitucci, S., \& Cedillo, M. (2003). Transforming the army through spiritual leadership. Unpublished manuscript. Tarleton State University-Central Texas, Killeen, TX. Available: http://www.tarleton.edu/ fry/resources.html.

Fry, W. L., \& Matherly, L. L. (2006). Spiritual Leadership and Organizational Performance: An Exploratory Study. Tarleton State University - Central Texas. http://precisionmi.com/Materials/LeadershipMat/Spiritual\%20Leadership\%20and\%20Organi zational\%20Performance\%20-\%20An\%20Exploratory\%20Study.pdf

Fry, W. L., Nisiewicz, M., Vitucci, S., \& Cedillo, M. (2007). Transforming City Government Through Spiritual Leadership: Measurement and Establishing a Baseline. Killeen, TX 76549

Fry, L. W., Matherly, L. L., Whittington, J. L., \& Winston, B. E. (2007). Spiritual Leadership as an Integrating Paradigm for Servant Leadership. Macmillan India Ltd. 70-82.

Giacalone, R. A., \& Jurkiewicz, C. L. (2003). Toward a science of workplace spirituality. In R. A. Giacalone\& C. L. Jurkiewicz (Eds.). Handbook of workplace spirituality and organizational performance: 3-28. New York: M.E. Sharp.

Hendricks, K. T., \& Hendricks, C. G. (2003). Operational integrity: The gateway to workplace harmony and velocity. In R. A. Giacalone, \& C. L. Jurkiewicz (Eds.), Handbook of workplace spirituality and organizational performance (pp. 429-445). New York7 M.E. Sharpe.

Hicks, D. A. (2002). Spiritual and religious diversity in the workplace: Implications for leadership. The Leadership Quarterly, 13(2), 379-396. https://doi.org/10.1016/S1048-9843(02)00124-8

Korac-Kakabadse, N., A. Kouzmin, \& A. Kakabadse. (2002). Spirituality and leadership praxis. Journal of Managerial Psychology, 17(3), 165-182. https://doi.org/10.1108/02683940210423079

Kouzes, J. M., \& Posner, B. Z. (1993). Credibility: How Leaders Gain and Lose It, Why People Demand It, Jossey Bass Publishers, San Francisco, CA.

Lewicki, R., Dineen, B., and Tomlinson, E. (2001). Coaching versus modeling: Examining supervisory impact on climate and attitudinal outcomes at the branch level of analysis. Paper presented at the Academy of Management Conference, Ishington, D.C., August.

Mansor, N., Ismail, A. H., Alwi, M. A. M., \& Anwar, N. (2013). Relationship between Spiritual Leadership and Organizational Commitment in Malaysians' Oil and Gas Industry. Asian Social Science, 9(7), 179-191. https://doi.org/10.5539/ass.v9n7p179

McLaughlin, C. (2005). Spiritual Politics: Innovative Approaches. The Center for Visionary 
Leadership. Available at http://www.visionarylead.org/articles/sp_approaches.htm

Morgan, R. B. (1993). Self- and co-worker perceptions of ethics and their relationships to leadership and salary. Academy of Management Journal, 36(1), 200-214. https://doi.org/10.2307/256519

Neal, J. A. (2001). Leadership and spirituality in the workplace. In R. N. Lussier\& C. F. Achua (Eds.), Leadership theory, application, skill development: 464-473. Boston: South-Western College Publishing.

Newman, L. L. (2004). Faith, Spirituality, and Religion: A Model for Understanding the Differences. Special Issue on Faith, Spirituality, and Religion on Campus, 23(2).

Nyhan, R. C., \& Marlowe, H. A. (1997). Development and psychometric properties of the organizational trust inventory. Evaluation Review, 21(5), 614-35. https://doi.org/10.1177/0193841X9702100505

O'Reilly, C. A., \& Pfeffer, J. (2000). Hidden value: How great companies achieve extraordinary results with ordinary people. Boston7 Harvard Business School Press.

Posner, B. Z., \& Schmidt, W. H. (1992). Values and the American manager: an update Updated. California Management Review, 34(3), 80-94. https://doi.org/10.2307/41167425

Reave, L. (2005). Spiritual values and practices related to leadership effectiveness. The Leadership Quarterly, 16, 655-687. https://doi.org/10.1016/j.leaqua.2005.07.003

Robertson, D. C., \& Anderson, E. (1993). Control system and task environment effects on ethical judgment: An exploratory study of industrial salespeople. Organization, 4(4), 617-629. https://doi.org/10.1287/orsc.4.4.617

Russell, R. F. (2001). The role of values in servant leadership. Leadership \& Organization Development Journal, 22(2), 76-83. https://doi.org/10.1108/01437730110382631

Sendjaya, S. (2007). Conceptualizing and Measuring Spiritual Leadership in Organizations. International Journal of Business and Information, 2(1), 104-126.

Skolimowski, H. (1999). Dharma, Ecology, and Wisdom in the Third Millennium. The Meaning of Politics in a Spiritual Perspective. Concept Publishing Company, 1999.

Van Velsor, E., Taylor, S., \& Leslie, J. (1993). An examination of the relationships among self-perception, accuracy, self-awareness, gender, and leader effectiveness. Human Resource Management, 32, 249-264. https://doi.org/10.1002/hrm.3930320205

Yavuz, M. H. (2004). Is There a Turkish Islam? The Emergence of Convergence and Consensus. Journal of Muslim Minority Affairs, 24(2), 213-232. https://doi.org/10.1080/1360200042000296627

Zinnbauer, B. J., Pargament, K. I., \& Scott, A. B. (1999). The emerging meanings of religiousness and spirituality: Problems and prospects. Journal of Personality 67(6). https://doi.org/10.1111/1467-6494.00077 